\title{
PERAN PT. KAWANUA KAHURIPAN PANTERA (KKP) TERHADAP KONDISI SOSIAL EKONOMI MASYARAKAT DI KECAMATAN PINOLOSIAN, KABUPATEN BOLAANG MONGONDOW SELATAN
}

\author{
Angelina Tumandung \\ Theodora M. Katiandagho \\ Eyverson Ruauw
}

\begin{abstract}
This study aims to see how big the role of PT. Kawanua Kahuripan Pantera (KKP) Against the economic social conditions of Pinolosian District of South Bolaang Mongondow District.The study was conducted from November 2016 to July 2017 (from preparation to report generation). The data used is primary data. This research is done by direct interview technique with company leader, employees as much (30 people), and Village Head (Sangadi) Pinolosian Subdistrict. The data obtained will be analyzed using descriptive analysis and will be presented in tabular form. The results of this study indicate the role of PT. KKP to socio-economic of Pinolosian Sub-district is public facility (Help for mosque and church worship place such as material fund for development and renovation), mangrove planting as many as 935 trees, clove pod assistance 26,510 pieces, job opportunity (Job Opening). In addition the company also provides health benefits for workers and affects the economy (Income) of the workers.
\end{abstract}

Keywords: role, socio-economic conditions of community, PT. Kawanua Kahuripan Pantera, Pinolosian Sub-district, South Bolaang Mongondow District.

\begin{abstract}
ABSTRAK
Penelitian ini bertujuan untuk melihat seberapa besar peran PT. Kawanua Kahuripan Pantera (KKP) terhadap kondisi sosial ekonomi masyarakat Kecamatan Pinolosian Kabupaten Bolaang Mongondow Selatan. Penelitian ini dilaksanakan pada bulan November 2016 hingga Juli 2017 (mulai dari persiapan sampai pembuatan laporan). Data yang digunakan adalah data primer. Penelitian ini dilakukan dengan teknik wawancara langsung dengan pimpinan perusahaan, karyawan sebanyak (30 orang), dan Kepala Desa (Sangadi) Kecamatan Pinolisian. Data yang diperoleh akan dianalisis mengunakan analisis deskriptif dan akan disajikan dalam bentuk tabel. Hasil penelitian ini menunjukkan peran PT. KKP terhadap sosial ekonomi masyarakat Kecamatan Pinolosian yaitu fasilitas umum (bantuan untuk tempat beribadah untuk masjid dan gereja seperti bantuan dana material untuk pembangunan dan renovasi), penanaman mangrove sebanyak 935 pohon, bantuan polong cengkeh 26.510 buah, kesempatan kerja (terbukanya lapangan pekerjaan). Selain itu perusahaan juga memberikan jaminan kesehatan bagi para pekerja dan mempengaruhi ekonomi (pendapatan) dari para pekerja.
\end{abstract}

Kata kunci: peran, kondisi sosial ekonomi masyarakat, PT. Kawanua Kahuripan Pantera, Kecamatan Pinolosian, Kabupaten Bolaang Mongondow Selatan 


\section{PENDAHULUAN}

\section{Latar Belakang}

Indonesia merupakan negara agraris yang memiliki potensi besar dan sumber daya alam yang melimpah untuk produk pertanian. Di sektor pertanian Indonesia memiliki beragam jenis tanaman, hal ini didukung kondisi iklim tropis yang berbeda, dibidang tanaman pangan di Indonesia memiliki tanaman unggul seperti padi, kedelai, kacang tanah, ubi kayu, cengkeh dan berbagai jenis farietas yang lain. Indonesia berpeluang menjadi negara maju di bidang ekonomi, khususnya dari sektor pertanian. Bahkan Indonesia diprediksi mampu memenuhi kebutuhan pangan dunia, sehingga disegani negara-negara lain (Sajogyo, 2002).

Sektor pertanian sebagai salah satu sektor ekonomi termasuk sektor yang sangat potensial dalam memberikan sumbangan terhadap pertumbuhan dan pembangunan ekonomi nasional, baik dari segi pendapatan maupun penyerapan tenaga kerja. Peranan sektor pertanian dalam pembangunan Indonesia sudah tidak perlu diragukan lagi. Di samping itu, usaha dalam sektor pertanian akan selalu berjalan selama manusia masih memerlukan makanan untuk mempertahankan hidup dan manusia masih memerlukan hasil pertanian sebagai bahan baku dalam industrinya.

Pembangunan seringkali dikaitkan dengan industrialisasi, dimana industrialisasi merupakan upaya sadar dan terencana dalam rangka mengelola dan memanfaatkan sumber daya guna mencapai tujuan pembangunan yakni meningkatkan kualitas kehidupan masyarakat dan bangsa. Perkembangan industri memang membawa akibat-akibat positif bagi kehidupan manusia, hakekat perkembangan industri akan selalu berarti bagi perkembangan peradaban manusia, dan lebih konkrit lagi perkembangan industri akan selalu berarti pula bagi peningkatan kesejahteraan masyarakat (Fardani, 2012).

Peluang-peluang agribisnis yang tercipta akan menimbulkan stimulan terhadap investasi dibidang agribisnis, yang dikuti dengan berdirinya perusahaan-perusahaan perkebunan cengkih. Berdirinya perusahaan-perusahaan tertentu disuatu daerah akan berpengaruh secara makro terhadap perekonomian nasional serta memiliki dampak terhadap kondisi sosial ekonomi masyarakat disekitar perusahaan itu didirikan.

Keberadaan perusahaan di tengah-tengah masyarakat merupakan wujud dan partisipasi dalam peningkatan dan pengembangan pembangunan masyarakat. Perusahaan dan masyarakat yang bermukim di sekitarnya merupakan dua komponen yang saling mempengaruhi. Dimana perusahaan memerlukan masyarakat sekitar dalam pengembangan perusahaan itu sendiri begitupun sebaliknya, masyarakat memerlukan perusahaan tersebut dalam peningkatan perekonomian masyarakat serta pengembangan daerah akibat keberadaan perusahaan tersebut. Oleh karena itu, aktivitas perusahaan tidak dapat dipungkiri memiliki dampak sosial terhadap masyarakat sekitarnya (Basuki, 2007).

Perusahaan perkebunan menjadi salah satu sektor utama dalam tatanan ekonomi. Perusahaan perkebunan dalam banyak kasus memiliki posisi dominan dalam pembangunan sosial ekonomi. Sektor perkebunan ini berdampak signifikan dalam arti positif maupun negatif. Dalam dampak positif yaitu sektor perkebunan ini mampu meningkatkan pendapatan asli daerah (PAD), menciptakan lapangan pekerjaan bagi masyarakat, meningkatkan ekonomi dan pembangunan. Sedangkan dampak negatif dalam sosial, lingkungan, politik, dan budaya yang ditimbulkan oleh sektor industri ini dimana untuk menjaga kelestarian lingkungan hidup.

Berdasarkan hal tersebut diatas berdirinya PT. Kawanua Kahuripan Pantera (KKP) yang berada di Desa Lungkap Kecamatan Pinolosian Bolaang Mongondow Selatan tentu memiliki pengaruh terhadap kondisi sosial ekonomi masyarakat disekitar lokasi perkebunan tersebut. Perubahan yang terjadi akibat berdirinya perusahaan perkebunan cengkih akan menimbulkan dampak sosial dan ekonomi, adapun dampak sosial yang terjadi yaitu berubahnya gaya hidup masyarakat seperti bagaimana manusia dan masyarakat itu hidup, bekerja, bermain, berinteraksi satu dengan yang lain, perubahan budaya yaitu sistem nilai, norma dan kepercayaan. 
PT. Kawanua Kahuripan Pantera (KKP) merupakan salah satu perusahaan yang mengelolah tanaman cengkeh yang diharapkan menjadi penyumbang penghasilan terbesar bagi kegiatan perusahaan di masa depan selain produk-produk lainnya seperti kayu, vanili, dan ecotourisme. Kegiatan perkebunan cengkeh di Kecamatan Pinolisian ini dimulai sejak tahun 2002 sejak diterimanya SK dari Bupati Bolaang Mongondow. PT. KKP merupakan subsidiary dari PT. Matahari Kahuripan Indonesia yang awal berdirinya pada tahun 2000. PT. KKP merupakan salah satu perusahaan yang memberikan dampak bagi kehidupan masyarakat desa dilihat dari aspek sosial yang meliputi peran serta perusahaan terhadap masyarakat pekerja PT. KKP dan kesadaran mutu pendidikan anak dari pekerja PT. KKP. Sedangkan aspek ekonomi yaitu pendapatan pekerja PT. KKP dan kesempatan kerja (Terbukanya lapangan pekerjaan).

Masyarakat Kecamatan Pinolosian mayoritas memiliki pekerjaan sebagai petani dan nelayan, selebihnya sebagai tukang ojek, pedagang dan pegawai negeri sipil (PNS). Dari jenis pekerjaan tersebut bisa dikatakan PNS memiliki penghasilan yang tetap dibandingkan dengan pekerjaaan lain seperti nelayan, tukang ojek, dan pedagang. PT. KKP bisa dikatakan menjadi jawaban bagi masyarakat yang tidak memiliki pekerjaan maupun yang sudah memiliki pekerjaan namun memiliki penghasilan yang tidak seberapa (tidak tetap).

PT. KKP memberikan kesempatan kepada masyrakat sekitar untuk bekerja baik sebagai karyawan tetap maupun sebagai buruh harian. Dalam kegiatan perkebunan di perusahaan ini masyarakat baik laki-laki maupun perempuan dapat terlibat mulai dari proses budidaya sampai pada pasca panen.

Berdasarkan permasalahan tersebut diatas peneliti tertarik untuk melakukan penelitian dengan judul peran PT. Kawanua Kahuripan Pantera (KKP) terhadap kondisi sosial ekonomi masyarakat Kecamatan Pinolosian Kabupaten Bolaang Mongondow Selatan.

\section{Rumusan Masalah}

Berdasarkan latar belakang yang sudah dipaparkan diatas rumusan masalah yang akan dibahas adalah Bagaimana peran PT. KKP terhadap kondisi sosial ekonomi masyarakat Kecamatan Pinolosian Kabupaten Bolaang Mongondow Selatan?

\section{Tujuan Penelitian}

Tujuan dari penelitian ini adalah untuk mengetahui peran PT. KKP terhadap kondisi sosial ekonomi masyarakat Kecamatan Pinolosian Kabupaten Bolaang Mongondow Selatan.

\section{Manfaat Penelitian}

Manfaat dari penelitian ini yaitu :

1. Dapat menambah pengetahuan mahasiswa dalam mempelajari perusahaan-perusahaan yang bergerak dibidang perkebunan baik dampak positif maupun negatif yang ditimbulkan oleh perusahaan.

2. Diharapkan penelitian ini menjadi bahan masukan bagi pemerintah Kecamatan Pinolosian Kabupaten Bolaang Mongondow Selatan dan pihak PT. KKP sendiri dalam memperhatikan dampak sosial maupun ekonomi yang timbul akibat beroperasinya perusahaan tersebut di lingkungan masyarakat Pinolosian.

\section{METODOLOGI PENELITIAN}

\section{Waktu dan Tempat Penelitian}

Penelitian dilaksanakan selama 9 bulan yaitu bulan November 2016 sampai bulan Juli 2017 (mulai dari persiapan sampai pembuatan laporan) dengan menetapkan lokasi peneletian di PT. Kawanua Kahuripan Pantera (KKP) Kecamatan Pinolosian Kabupaten Bolaang Mongondow Selatan.

\section{Metode Pengumpulan Data}

Metode yang digunakan dalam penelitian ini adalah situasi kerja pada PT. Kawanua Kahuripan Pantera (KKP). Data yang dikumpulkan adalah data primer yaitu data yang diperoleh langsung dilapangan dengan mengajukan pertanyaan/wawancara langsung menggunakan kuesioner terhadap pimpinan perusahaan, karyawan, dan kepala desa (sangadi) Kecamatan Pinolosian. 
Jumlah responden karyawan sebanyak 30 orang diambil secara acak dengan memberikan nomor kepada masing-masing responden karyawan PT. KKP.

\section{Konsep Pengukuran Variabel}

Konsep pengukuran kondisi sosial dan ekonomi pekerja PT. KKP terhadap masyarakat Desa Kecamatan Pinolosian yaitu sebagai berikut:

1. Aspek sosial yaitu :

a. Fasilitas Umum.

b. Jaminan Sosial pekerja KKP.

c. Kesadaran Mutu Pendidikan Anak dari Pekerja PT. KKP.

2. Aspek ekonomi yaitu :

a. Pendapatan (Ekonomi keluarga pekerja PT. KKP).

b. Kesempatan Kerja (Terbukanya Lapangan Pekerjaan).

\section{Metode Analisis Data}

Metode analisis data yang digunakan dalam penelitian ini adalah analisis deskriptif yaitu mendeskripsikan atau menggambarkan data-data yang sudah dikumpulkan dalam bentuk tabel.

\section{HASIL DAN PEMBAHASAN}

\section{Deskripsi Wilayah Penelitian}

Kecamatan Pinolosian sebagai lokasi penelitian pada awalnya adalah sebuah desa Pinolosian. Desa Pinolosian pada awalnya dipimpin oleh Mamuasa Mokoagow selaku sangadi atau kepala desa yang pertama. Kecamatan Pinolosian adalah Kecamatan di Kabupaten Bolaang Mongondow Selatan yang berpusat pemerintahan di Desa Pinolosian yang dibentuk pada tahun 1954. Pada awalnya Kecamatan Pinolosian hanyalah 12 desa yaitu Desa Linawan, Nunuk, Torosik, Kombot, Lungkap, Mataindo, Tobayagan, Matandoi, Dumagin A, Dumagin B dan Onggunai dan kemudian pada tahun 1980 ditambah 1 desa yaitu Ilomata. Pada Januari 2005 terjadi pemekaran Kecamatan yaitu Kecamatan Pinolosian Timur dan tahun 2006 terjadi lagi pemekaran yaitu Kecamatan Pinolosian Tengah dengan jumlah desa 5 desa sehingga Kecamatan Pinolosian kurang 6 desa, kemudian pada tahun 2007 terjadi pemekaran desa yaitu 3 desa masing-masing Linawan 1, Pinolosian Selatan, dan Tolotoyon dan pada tahun 2012 terjadi lagi pemekaran desa yaitu Desa Kombot Timur, hingga Kecamatan Pinolosian semuanya menjadi 10 desa definitif.

Kecamatan Pinolosian 285,94 km2 dengan posisi daratan terletak pada ketinggian 50 meter dari permukaan laut. Secara geografis Kecamatan Pinolosian terbagi atas batas administrasi sebagai berikut:

1. Sebelah Timur berbatasa dengan Kecamatan Pinolosian Tengah.

2. Sebelah Utara berbatasan dengan Kecamatan Dumoga dan Lolayan.

3. Sebelah Selatan dengan Laut Maluku.

4. Sebelah Barat dengan Kecamatan Bolaang Uki.

Diwilayah Kecamatan Pinolosian memiliki 2 lokasi perkebunan yaitu PT. Perkebunan Tolotoyon bergerak dibidang perkebunan kelapa dan PT. Kawanua Kahuripan Pantera (KKP) berada di Kecamatan Pinolosian tepatnya di Desa Lungkap. Penduduk di Kecamatan Pinolosian pada saat penelitian yang diambil dari dokumen di Kantor Badan Pusat Statistika dalam "Katalog Kecamatan Pinolosian 2012" berjumlah 9.778 jiwa Kecamatan Pinolosian masyarakatnya menganut 3 kepercayaan yaitu agama Islam sebagai mayoritas, dan minoritas agama Kristen dan Hindu. Masyarakat Pinolosian adalah masyarakat yang terdiri dari berbagai etnik yaitu etnik Mongondow sebagai mayoritas, dan etnik minoritas seperti Gorontalo yang tersebar di 2 Desa Kecamatan Pinolosian yaitu Desa Linawan dan Desa Ilomata. Selain etnik Gorontalo ada juga etnik Minahasa, Sanger, Bali, Bugis dan Jawa.

\section{Deskripsi PT. Kawanua Kahuripan Pantera (KKP)}

\section{Sejarah Perusahaan}

PT. Kawanua Kahuripan Pantera berada di Kecamatan Pinolosian $\pm 7 \mathrm{~km}$ dari Desa Lungkap, $\pm 116 \mathrm{~km}$ dari Kota Kotamobagu, dan sekitar $285 \mathrm{~km}$ dari Kota Manado. Didirikan 
pada tahun 2000 dengan akte notaris No. 08 Tanggal 30 Oktober 2000 dari notaries Ny. Bertha Suriati Ihalauw Halim. PT. Kawanua Kahuripan Pantera merupakan subsidiary PT. Matahari Kahuripan Indonesia (MAKIN GROUP). PT. KKP memperoleh IUPHHK: SK Bupati Bolaang Mongondow No. 153 tanggal 31 Mei Tahun 2002.

\section{Aktivitas Bisnis PT. KKP}

PT. Kawanua Kahuripan Pantera (KKP) merupakan perusahaan yang bergerak di bidang pertanian yaitu perkebunan cengkih dengan luas lahan sekitar $4.808 \mathrm{Ha}, 1.745 \mathrm{Ha}$ ditanami tanaman unggulan mereka yaitu cengkih. Selain tanaman cengkih perusahaan juga menanam tanaman seperti vanili, cokelat dan kayu gaharu. Untuk kayu gaharu perusahaan menanamnya diantara tanaman cengkih agar dapat menahan deras aliran air yang akan berdampak pada pengikisan tanah (erosi). Adapun lahan sekitar 317,82 Ha merupakan kebun mitra (Plasma Cengkih) yaitu lahan milik masyarakat yang termasuk dalam area lahan perusahaan sehingga, perusahaan menawarkan kerjasama berupa sistem bagi hasil dimana perusahaan yang mengelolah lahan milik masyarakat tersebut sampai masyarakat hanya tinggal menerima hasil bersih saja. Dengan perjanjian bagi hasil $70 \%$ untuk masyarakat dan $30 \%$ sisanya untuk perusahaan.

\section{Tenaga Kerja PT. KKP}

Tenaga kerja yang bekerja pada PT. Kawanua Kahuripan Pantera 95\% berasal dari desa-desa sekitar perusahaan dengan jenis pekerjaan yang berbeda-beda. Tenaga kerja yang bekerja di perusahaan ini juga dibedakan menjadi pegawai, tenaga kontrak dan buruh harian lepas. Pekerja yang termasuk dalam buruh harian lepas yaitu mereka yang bekerja dibagian persemaian, pemetikan, dan pembersihan. Buruh harian lepas ini pada umumnya sangat dibutuhkan pada saat panen karena pada proses ini sangat membutuhkan banyak pekerja.

Tenaga kerja PT. KKP diberikan kemudahan untuk akses ke perusahaan, dimana perusahaan menyediakan sarana transportasi bagi para pekerja (antar-jemput) agar para pekerja bisa dengan mudah pergi ke tempat bekerja. Untuk sistem pengajian dari para pekerja ini berbeda-beda tergantung jenis pekerjaannya, namun untuk pegawai tetap bisa memiliki gaji minimal UMP bahkan ada yang sampai lebih dari itu. Sedangkan, untuk jenis pekerjaan pemetikan dan pembersihan dihitung dari banyaknya hasil yang mereka petik dan bersihkan. Untuk pekerjaan pemetikan biasanya pekerja diberikan upah sekitar Rp.4.500/kg dan pekerjaan ini biasanya dikerjaan oleh laki-laki namun ada juga beberapa wanita yang bisa melakukan pekerjaan ini, sedangkan untuk pekerjaan bacude biasanya dikerjakan oleh ibu-ibu dimana pekerjaan ini bisa dikerjakan dalam perusahaan dan ada juga dibalai-balai desa setempat. Untuk ibu-ibu yang bekerja dalam perusahaan, perusahaan menyediakan transportasi untuk mengangkut para pekerja (antar-jemput) sedangkan dibalai desa perusahaan yang mengantar cengkih langsung ke balai desa dengan upah pekerja pembersihan digaji sekitar Rp.1.750/kg.

\section{Fasilitas Penunjang}

PT. Kawanua Kahuripan Pantera menyediakan fasilitas penunjang untuk para tenaga kerja tetap (kepala-kepala resort) pada perusahaan seperti : kantor induk, gudang, workshop, perumahan karyawan, rumah ibadah, guesthouse, dan kantin. Untuk masyarakat Kecamatan Pinolosian perusahaan menyediakan bantuan berupa koperasi sebanyak 3 unit yang berada di Desa Lungkap, Kombot, Mataindo.

\section{Karakteristik Responden}

\section{Umur}

Pekerjaan pada PT. Kawanua Kahuripan Pantera (KKP) memiliki umur bervariasi, dari umur 20-an tahun sampai yang berumur 60-an tahun. Hal ini disebabkan tidak adanya batasan umur untuk bekerja pada perusahaan tersebut. Pengelompokkan umur responden dilakukan 
untuk melihat kemampuan kerja dari para pekerja tersebut.

Tabel 1. Umur Responden yang bekerja pada PT. KKP tahun 2016

\begin{tabular}{ccc}
\hline $\begin{array}{c}\text { Kelompok umur } \\
\text { (Tahun) }\end{array}$ & $\begin{array}{c}\text { Responden } \\
\text { (Orang) }\end{array}$ & $\%$ \\
\hline$<30$ & 10 & 33,33 \\
$30-40$ & 11 & 36,67 \\
$40-50$ & 4 & 13,33 \\
$50-60$ & 3 & 10,00 \\
$>60$ & 2 & 6,67 \\
\hline Jumlah & 30 & 100 \\
\hline
\end{tabular}

Sumber: Diolah dari data primer 2016

Berdasarkan Tabel 1 dapat dilihat bahwa umur responden yang bekerja pada perusahaan KKP paling banyak kelompok umur $30-40$ yaitu 11 orang $(36,67 \%)$ selanjutnya kelompok umur $<30$ yaitu 10 orang $(33,33 \%)$ dimana pada 2 kelompok ini merupakan kelompok usia produktif. Dilihat dari kelompok usia para pekerja jenis pekerjaan yang tepat untuk pekerja usia produktif seperti pada Tabel 1 yaitu sebagai buruh harian lepas, tenaga kontrak (yaitu bekerja di lahan, bagian gudang, bagian alat berat, supir kendaraan perusahaan) karena di usia seperti ini pekerja cenderung lebih mampu bekerja dengan baik dan lebih cepat dibandingkan tenaga kerja diatas usia 50-an tahun.

\section{Jenis Kelamin}

Pekerjaan pada PT. KKP tidak hanya ditekuni oleh tenaga kerja laki-laki saja, namun tenaga kerja perempuan juga diperlukan dalam kegiatan perkebunan cengkih ini. Pekerjaan tenaga kerja laki-laki memang berbeda dengan tenaga kerja perempuan dimana tenaga kerja perempuan bekerja pada proses pembersihan. Tenaga kerja wanita sangat dibutuhkan dalam proses ini dimana proses ini membutuhkan waktu, kesabaran dan ketelitian untuk memisahkan bunga cengkih dari tangkainya untuk mendapatkan mutu yang baik dari hasil produksi. Tenaga kerja laki-laki melakukan pekerjaan yang berat seperti membawa alat berat untuk pembukaan lahan baru, supir untuk menjemput dan mengantar tenaga kerja dari desa sekitar, proses budidaya yaitu pembibitan, penanaman, pengendalian hama dan penyakit sampai pada saat panen. Dimana tenaga kerja laki-laki memiliki peran yang lebih besar dibandingkan tenaga kerja wanita dalam kegiatan industri perkebunan berikut ini memperlihatkan mengenai banyaknya tenaga kerja yang bekerja pada kegiatan industri perkebunan di PT. KKP.

\section{Tabel 2. Jenis Kelamin Responden yang bekerja di PT. KKP Kecamatan Pinolosian 2016}

\begin{tabular}{lcc}
\hline Jenis Kelamin & $\begin{array}{c}\text { Responden } \\
\text { (Orang) }\end{array}$ & $\%$ \\
\hline Laki- laki & 23 & 76,67 \\
Perempuan & 7 & 23,33 \\
\hline Jumlah & 30 & 100 \\
\hline
\end{tabular}

Sumber: Diolah dari data primer 2016

Dari Tabel 2 dapat dilihat bahwa tenaga kerja laki-laki yang bekerja di PT. KKP berjumlah 23 orang $(76,67 \%)$ dibandingkan dengan tenaga kerja perempuan yang lebih sedikit jumlahnya yaitu 7 orang $(23,33 \%)$. Hal ini dikarenakan tenaga kerja laki-laki memang lebih banyak berperan dalam kegiatan perkebunan (sektor pertanian) tersebut. Tenaga kerja perempuan lebih banyak dibutuhkan pada saat panen karena perusahaan membutuhkan banyak tenaga untuk melakukan proses pemetikan dan pemitil, dan hal ini menguntungkan untuk masyarakat Kecamatan Pinolosian khususnya IRT yangtidak memiliki pekerjaan sehingga memiliki pekerjaan sebagai buruh harian lepas (BHL) pada persuhaan, begitu juga tenaga kerja laki-laki juga yang bekerja sebagai buruh harian lepas.

\section{Pendidikan}

Pendidikan para pekerja pada umumnya beragam, mulai dari tamat SD hingga yang berhasil tamat SMA sederajat. Tenaga kerja yang bekerja pada perusahaan KKP juga tidak memiliki ketentuan atau batasan untuk pendidikan tenaga kerja terlebih dalam hal sebagai buruh harian lepas (BHL). 
Tabel 3. Tingkat Pendidikan Responden yang bekerja di PT. KKP Kecamatan Pinolosian 2016

\begin{tabular}{lcc}
\hline Tingkat Pendidikan & $\begin{array}{c}\text { Responden } \\
\text { (Orang) }\end{array}$ & $\%$ \\
\hline SD & 7 & 23,33 \\
SMP & 13 & 43,33 \\
SMA & 10 & 33,33 \\
\hline Jumlah & 30 & 100
\end{tabular}

Sumber: Diolah dari data primer 2016

Dari Tabel 3 dapat dilihat bahwa responden (masyarakat) yang bekerja di PT. KKP yaitu paling banyak tamat SMP sebanyak 13 orang $(43,33 \%)$, selanjutnya tamat SMA sebanyak 10 orang $(33,33 \%)$, dan SD sebanyak 7 orang $(23,33 \%)$. Tingkat pendidikan untuk responden atau pekerja yang bekerja pada PT. KKP khususnya kantor memang memiliki batasan tingkat pendidikan hal ini ditentukan karena untuk mengurus atau dalam pekerja kantor biasanya membutuhkan pekerja yang harus memiliki latar belakang pendidikan yang baik, sedangkan untuk BHL dan pegawai kontrak tidak memandang latar belakang pendidikan dari para pekerja karena pekerjaan yang dikerjakan tidak menyangkut data-data melainkan lebih ke kegiatan fisik sehingga hal ini merupakan sesuatu yang positif untuk masyarakat yang ingin bekerja disitu terutama masyarakat yang hanya memiliki latar belakang yang rendah.

\section{Peran PT. Kawanua Kahuripan Pantera (KKP) Terhadap Kondisi Sosial Masyarakat Sekitar Lokasi PT. KKP}

Kehadiran PT. KKP membawa pengaruh bagi masyarakat Kecamatan Pinolosian dalam hal memberikan bantuan bagi masyarakat berupa fasilitas umum dan kesempatan kerja (terbukanya lapangan pekerjaan) yaitu sebagai berikut:

\section{Fasilitas Umum}

Fasilitas umum merupakan fasilitas yang diadakan untuk kepentingan umum. Contoh dari fasilitas umum yaitu seperti jalan, angkutan umum, rumah sakit, pendidikan, tempat perbelanjaan, perhotelan, halte, alat penerangan umum, pariwisata, jalur busway, tempat pembuangan sampah, dsb. Adanya PT. KKP di Kecamatan Pinolosian diakui oleh masyarakat membantu masyarakat dalam hal fasilitas umum seperti yang dapat dilihat dari Tabel 4 yaitu:

Tabel 4. Pendapat Masyarakat Tentang Peran PT. KKP Terhadap Bantuan Fasilitas Umum Bagi Masyarakat Kecamatan Pinolosian.

\begin{tabular}{ll}
\hline Pendapat Masyarakat & Bentuk Fisik \\
\hline $\begin{array}{l}\text { Bantuan Untuk Tempat } \\
\text { Ibadah: } \\
\text { Bantuan dana untuk } \\
\text { pembuatan plafon Masjid di } \\
\text { desa Ilomata }\end{array}$ & 1 Masjid \\
$\begin{array}{l}\text { Bantuan semen } \\
\text { pembangunan masjid di desa } \\
\text { Kombot }\end{array}$ & $\begin{array}{l}40 \text { sak semen (1 } \\
\text { Menjid) }\end{array}$ \\
\hline $\begin{array}{l}\text { Renovasi gedung gereja di } \\
\text { desa Tolotoyon }\end{array}$ & 1 Gereja \\
\hline Pemberian Polong Cengkeh & 26.510 buah \\
\hline Penanaman Mangrove & 935 pohon \\
\hline
\end{tabular}

Sumber: PT. Kawanua Kahuripan Pantera 2016

Berdasarkan data pada Tabel 4 dapat dilihat peran PT. KKP terhadap kegiatan masyarakat Kecamatan Pinolosian Kabupaten Bolaang Mongondow Selatan yaitu Bantuan untuk tempat beribadah dana untuk pembuatan plafon masjid di desa Ilomata (1 Masjid), bantuan semen untuk pembangunan masjid di desa Kombot (40 sak semen), bantuan dana untuk renovasi gedung gereja di Desa Tolotoyon (1 Gereja), pemberian polong cengkeh (26.510 buah), dan penanaman mangrove sebanyak 935 pohon.

\section{Kesempatan Kerja (Terbukanya Lapangan Pekerjaan)}

Kehadiran PT. KKP membawa pengaruh bagi kehidupan masyarakat Kecamatan Pinolosian. Pengaruh yang timbul bukan hanya dari segi sosial, namun dari segi ekonomi masyarakat Pinolosian mengalam perubahan. Perkembangan desa di Kecamatan Pinolosian bisa dikatakan karena adanya PT. KKP di daerah mereka. Adanya perusahaan ini menjadi pemicu masyarakat untuk bergerak lebih maju untuk mengatasi masalah-masalah sosial yang ada disekitarnya. Masyarakat secara langsung termotivasi untuk membuat suatu perubahan didalam hidup mereka dengan bekerja pada PT. 
KKP untuk meningkatkan taraf hidup mereka. Sebagian besar masyarakat yang berada di Kecamatan Pinolosian memiliki perkerjaan sebagai karyawan PT. KKP dimana sebelumnya masyarakat desa bekerja sebagai petani, nelayan beralih menjadi karyawan PT. KKP.

Tingkat upah yang lebih baik dari pekerjaan mereka membuat masyarakat memilih untuk bekerja di PT. KKP. Hal ini juga diakui oleh pihak perusahaan dimana $95 \%$ karyawan yang bekerja pada perusahaan merupakan tenaga kerja lokal yaitu masyarakat yang berdomisili di Kecamatan Pinolosian baik sebagai tenaga kerja tetap maupun tenaga kerja tidak tetap. Adanya perusahaan secara tidak langsung memberikan pengaruh positif bagi perkembangan desa berupa berkurangnya pengangguran di desa sekitar lokasi perusahaan.

\section{Peran PT. Kawanua Kahuripan Pantera (KKP) Terhadap Kondisi Sosial Pekerja pada PT. KKP}

Kesejahteraan pekerja pada suatu perusahaan ditentukan dari hasil/pendapatan yang mereka peroleh dari tempat mereka bekerja. Pengaruh perusahaan terhadap pekerja mempengaruhi kondisi sosial maupun ekonomi tenaga kerja seperti kesehatan, tingkat pendidikan, pendapatan, ekonomi keluarga yaitu sebagai berikut:

\section{Jaminan Sosial}

Kesehatan sangat berpengaruh pada cara kerja tenaga kerja. Kondisi kesehatan yang baik membuat para pekerja dapat bekerja dengan baik, untuk itu perusahaan menyediakan fasilitas kesehatan bagi karyawan perusahaan yaitu posko layanan kesehatan yang terdapat di area perusahaan sehingga pekerja yang merasakan gangguan kesehatan dapat segera diatasi. Selain posko layanan kesehatan perusahaan juga memberikanan jaminan ksehatan bagi para pekerja yaitu karyawan tetap pada perusahaan seperti jaminan kesehatan (BPJS), guna menunjang kesehatan karyawan sehingga para pekerja mendapat kemudahan dalam mendapatkan layanan kesehatan. Sedangkan bagi yang bukan karyawan tetap meski tidak mendapatkan jaminan kesehatan dari perusahaan namun pemerintah setempat juga memberikan bantuan jaminan kesehatan bagi mereka.

Pemberian bantuan kesehatan ini dikhususkan untuk masyarakat yang berpendapatan rendah (kurang mampu). Diakui oleh beberapa masyrakat yang juga pekerja pada perusahaan yang menerima bantuan jaminan kesehatan dari pemerintah ini mereka dapat berobat secara gratis di posko-posko layanan kesehatan setempat. Program bantuan kesehatan ini sangat menguntungkan bagi masyarakat, karena mereka tidak perlu lagi khawatir dengan masalah pembiayaan yang pada dasarnya menjadi beban bagi masyarakat berpendapatan rendah.

Tabel 5. Penerima Jaminan Kesehatan karyawan PT.

\begin{tabular}{|c|c|c|c|c|}
\hline$\overline{\text { No }}$ & Karyawan & $\begin{array}{c}\text { Jumlah } \\
\text { Karyawan } \\
(\%)\end{array}$ & $\begin{array}{c}\text { Penerima } \\
\text { Jaminan } \\
\text { Kesehatan } \\
(\%)\end{array}$ & $\begin{array}{r}\text { Total } \\
(\%)\end{array}$ \\
\hline \multirow{3}{*}{$\begin{array}{l}1 \\
2\end{array}$} & Karyawan Tetap & 200 & 200 & 100 \\
\hline & $\begin{array}{l}\text { Buruh harian } \\
\text { lepas (tenaga } \\
\text { pemetik dan } \\
\text { pembersihan) }\end{array}$ & 2.644 & - & - \\
\hline & Jumlah & 2.844 & 100 & 100 \\
\hline
\end{tabular}

Sumber: PT. Kawanua Kahuripan Pantera 2016

Berdasarkan Tabel 5 dapat dilihat karyawan tetap $100 \%$ menerima jaminan kesehatan sedangkan tenaga kerja buruh harian lepas tidak mendapat jaminan kesehatan. Jumlah buruh harian lepas setiap tahunnya dapat berubah tergantung dari hasil panen perusahaan.

\section{Kesadaran Mutu Pendidikan Anak dari Pekerja PT. KKP}

Tingkat pendidikan merupakan suatu proses yang sengaja dilakukan oleh pekerja PT. KKP untuk mengembangkan kepribadian dan kemampuan anak-anak mereka melalui pendidikan melebihi tingkat pendidikan mereka sebagai orang tua. Sebagian masyarakat desa yang bekerja sebagai pekerja di perusahaan umumya lulusan SD, SMP, dan lulusan SMA. Lulusan SMP masih mendominasi pendidikan masyarakat yang bekerja sebgai buruh harian lepas di perusahaan sekitar 13 orang dari total 30 responden merupakan tamatan SMP. 
Pekerja yang bekerja di PT. KKP 100\% terdorong untuk bekerja lebih giat demi menyekolahkan anak-anak mereka. Kesadaran akan mutu pendidikan yang tinggi, pemenuhan kebutuhan pendidikan membutuhkan dana yang cukup banyak sehingga membuat para pekerja harus berusaha untuk bekerja lebih giat agar dapat memenuhi semua kebutuhan tersebut. Beberapa responden yang bekerja di PT. KKP sebelumnya bekerja hanya sebagai nelayan, tukang, tukang ojek, petani dan beberapa juga hanya sebagi IRT. Dari jenis pekerjaan mereka sebelumnya diakui oleh responden mendapatkan penghasilan yang kurang seperti contohnya nelayan yang bekerja tergantung pada cuaca sedangkan mereka harus memenuhi kebutuhan sehari- hari dan kewajiban untuk menyekolahkan anak. Kesadaran pemenuhan kebutuhan dan kewajiban untuk menyekolahkan anak-anak ini yang membuat para pekerja bekeja di PT. KKP yang memberikan penghasilan cukup lebih dari pekerjaan mereka sebelumnya.

Sekitar $83 \%$ responden yang bekerja sebagai pekerja di PT. KKP memiliki anak dengan tingkat pendidikan sekarang SD mengaku merasa cukup dengan penghasilan mereka karena dapat menyekolahkan dan memenuhi kebutuhan pendidikan anak-anak melihat kebutuhan pendidikan sekarang semakin mahal dan kebutuhan sehari-hari mereka. Salah satu faktor yang mempengaruhi tingkat pendidikan menurut Hasbullhan, 2003 adalah sosial ekonomi dimana semakin tinggi sosial ekonomi memungkinkan seseorang mencapai tingkat pendidikan yang lebih tinggi.

\section{Pendapatan (Ekonomi Keluarga Pekerja PT. KKP)}

Keberadaan PT. KKP di Kecamatan Pinolosian sejak tahun 2002 memberikan dampak bagi masyarakat Kecamatan Pinolosian baik dampak sosial maupun ekonomi. Adanya perusahaan ini membuat masyarakat sekitar memiliki kesempatan kerja (terbukanya lapangan kerja) yang kemudian mempengaruhi kehidupan ekonomi mereka sebagai pekerja. Pendapatan yang cukup sebagai pekerja di PT. KKP membuat masyarakat Kecamatan Pinolosian lebih memilih bekerja diperusahaan dibandingkan dengan beberapa masyarakat lain yang dulu hanya bekerja sebagai nelayan yang memiliki penghasilan tidak tetap. Pendapatan pekerja berbeda-beda dari Rp.750.000,-/ bulan sampai diatas Rp.2.200.000,-/bulan. Tingkat pendapatan yang berbeda-beda dikarenakan jenis pekerjaan mereka juga berbeda, namun hal ini masih dirasa cukup oleh para pekerja.

Pendapatan para pekerja mempengaruhi ekonomi keluarga dari masing-masing pekerja dimana semakin tinggi pendapatan yang mereka peroleh, maka tingkat ekonomi mereka juga semakin tinggi. Berdasarkan hal tersebut artinya mereka sudah mampu memenuhi semua kebutuhan keluarga mereka masing-masing dari hasil yang mereka peroleh.

\begin{tabular}{cccc}
\multicolumn{3}{c}{ Tabel 6. Pendapatan Responden (Pekerja) } & Perbulan \\
di PT. KKP & & \\
\hline No & $\begin{array}{c}\text { Pendapatan } \\
(\text { Rp) }\end{array}$ & $\begin{array}{c}\text { Jumlah } \\
\text { (Responden) }\end{array}$ & $\begin{array}{c}\text { Total } \\
(\%)\end{array}$ \\
\hline 1 & $750.000-1.500 .000$ & 6 & 20 \\
2 & $1.500 .000-2.000 .000$ & 3 & 10 \\
3 & $2.000 .000-2.600 .000$ & 18 & 60 \\
4 & $2.600 .000-3.000 .000$ & 3 & 10 \\
\hline & Jumlah & 30 & 100 \\
\hline
\end{tabular}

Sumber: Diolah dari data primer 2016

Dari Tabel 6 dapat dilihat pendapatan Responden sebagai pekerja di PT. KKP sebanyak 60\% memiliki penghasilan dari Rp.2.000.000 - Rp.2.600.000, responden yang berpenghasilan Rp.2.600.000 - Rp.3.000.000 sebanyak 10\%, penghasilan Rp.1.500.000 Rp.2.000.000 sebanyak 10\% dan $20 \%$ berpengahasilan Rp.750.000 - Rp.1.500.000.

\section{KESIMPULAN DAN SARAN}

\section{Kesimpulan}

Peran PT. Kawanua Kahuripan Pantera (KKP) terhadap kondisi sosial ekonomi masyarakat Kecamatan Pinolosian yaitu fasilitas umum (bantuan untuk tempat beribadah untuk masjid dan gereja seperti bantuan dana dan material untuk pembangunan gedung dan renovasi, Penanaman mangrove sebanyak 935 pohon, dan bantuan pemberian polong cengkeh 26.510 buah) dan kesempatan kerja (terbukanya lapangan pekerjaan). Sedangkan Peran PT. KKP terhadap kondisi sosial ekonomi pekerja 
pada perusahaan yaitu berupa jaminan sosial (jaminan kesehatan) pekerja, kesadaran mutu pendidikan anak para pekerja, dan pendapatan (Ekonomi keluarga pekerja).

Dari hasil penelitian yang didapat adanya PT. Kawanua Kahuripan Pantera di Kecamatan Pinolosian Kabupaten Bolaang Mongondow Selatan cukup memberikan dampak positif bagi kehidupan masyarakat desa dan pekerja yang pada perusahaan terutama dalam hal kesempatan kerja (Terbukanya Lapangan Pekerjaan).

\section{Saran}

PT. Kawanua Kahuripan Pantera agar lebih memperhatikan kesejahteraan masyarakat Kecamatan Pinolosian yang bekerja sebagai buruh harian lepas di PT. KKP berupa peningkatan upah menurut yang responden masih kurang, dan tetap mempertahankan kerjasama dengan masyarakat sekitar perusahaan dengan tetap menyerap tenaga kerja dari masyarakat Kecamatan Pinolosian walaupun tidak menutup kemungkinan juga untuk masyarakat luar dan meningkatkan bantuan-bantuan berupa fasilitas umum untuk masyarakat desa Kecamatan Pinolosian.

\section{DAFTAR PUSTAKA}

Basuki A. S. 2007. Dampak Keberadaan Pertambangan Batu Bara PT Viktor Dua Tiga Mega terhadap Kondisi Sosial Ekonomi Masyarakat Disekitarnya (Studi Di Kecamatan Lahei Kabupaten Barito Utara Provinsi Kalimantan Tengah).

Fardani A. 2012. Dampak Sosial Keberadaan PT Vale Indonesia Tbk Terhadap Kehidupan Masyarakat (studi Kasus Sorowako Kecamatan Nuha Kabupaten Luhu Timur).

Sajogyo. 2002. Peranan Wanita Dalam Keluarga Rumah Tangga Dan Masyarakat Yang Lebih Luas Di Pedesaan. CV Rajawali. Jakarta. 